\title{
Development of Optically Driven Microgears by Using Two-photon Microstereolithography
}

\author{
Hiroyuki Inoue Non-member (Yokohama National University) \\ Seiji Haga Non-member (Yokohama National University) \\ Shoji Maruo Member (Yokohama National University, maruo@ynu.ac.jp)
}

Keywords : two-photon microstereolithography, optically driven microgears, optical trapping

Recently biochips have attracted much attention for their ability in ultra-fast, parallel microanalysis and their potential application in the area of biochemical analysis and medical diagnosis. Unlike conventional microelectromechanical devices, most of biochips need not built-in microactuators and electrical circuits but relative simple microstructures such as chambers and channels. This is because simple and low-cost devices are suitable for disposable use in biochemical research and medical diagnosis. For this reason, functional disposable biochips containing simple, low-cost micropumps and valves have been developed. Optically driven biochips are one of the most promising components for the advanced functional biochips because of the flexible remote control of various types of microcomponents with high precision. To realize the optically driven biochips, we have already developed optically driven micromachines such as microgears and nanotweezers by using two-photon microstereolithography. One of current issues of the optically driven micromachines is the improvement of their driving force. To improve the optical torque, the thickness of the movable parts must be increased.

In this report, we tried to control the thickness of the movable parts by changing the exposure conditions and numerical aperture of an objective lens in the two-photon microstereolithography. Fig. 1 shows the proper exposure region in the numerical aperture of 1.35. If the laser power is too low, photopolymer cannot be solidified. On the other hand, if the laser power is too high, a solidified structure is destroyed owing to laser breakdown. The proper exposure condition is limited in the narrow area. Therefore the NA of the objective lens should be reduced to increase the solidified line width in depth.

Fig. 2 (a), (b) show SEM images of microgears fabricated in different numerical apertures at each proper exposure condition. It was demonstrated that the thickness of movable microparts could be controlled with the optimization of both the numerical aperture and the exposure condition. The thickness was beyond $1.5 \mu \mathrm{m}$ with the numerical aperture of 0.95 .

Thick microgear can provide high optical torque because the

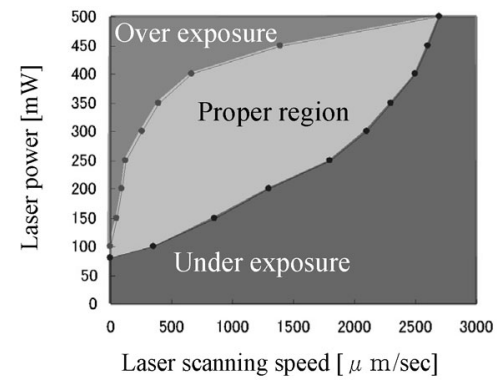

Fig. 1. Proper exposure conditions for stable fabrication optical force to move the movable microparts along the trajectory of the laser beam is generated at the side of the movable microparts. Fig. 3 shows the dependence of the revolution speeds of microgears on the thickness of the microgears. The revolution speed could be increased from $14.1 \mathrm{rpm}$ to $28.3 \mathrm{rpm}$.

In addition, we proposed a novel method to make engaged microgears as shown in Fig. 4(a). Two microgears are fabricated in different heights. The microgears could be engaged after washing out unsolidified photopolymer. Such thick engaged microgears will be useful for high power micromachines such as micopumps for biochips.

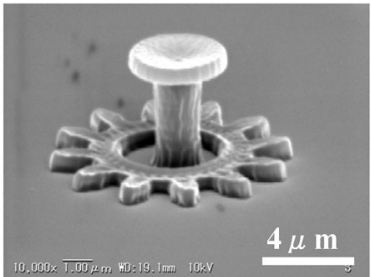

(a)

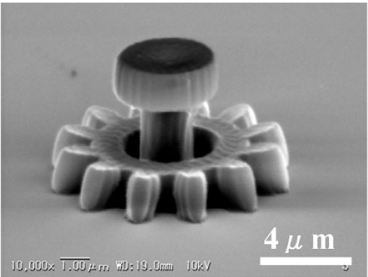

(b)
Fig. 2. Microgears fabricated with different numerical apertures

(a) NA: 1.25 , Laser Power: $100 \mathrm{~mW}$, Thickness: $0.59 \mu \mathrm{m}$,

(b) NA: 0.95, Laser Power: 250mW Thickness: $1.57 \mu \mathrm{m}$

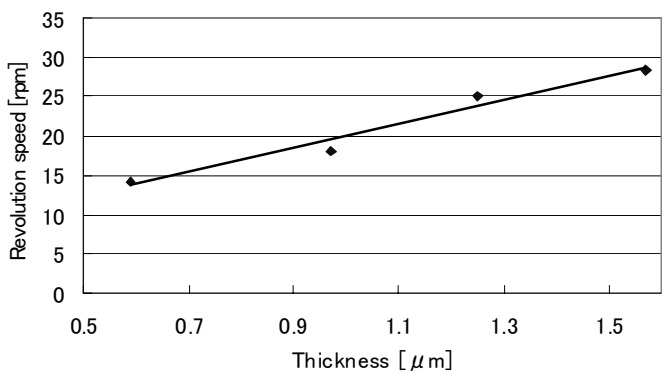

Fig. 3. Dependence of revolution speed on the thickness of microgears

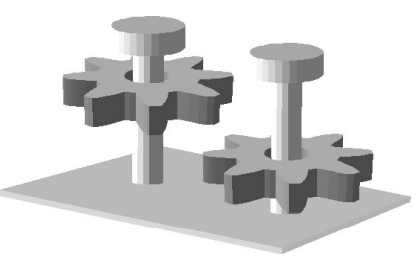

(a)

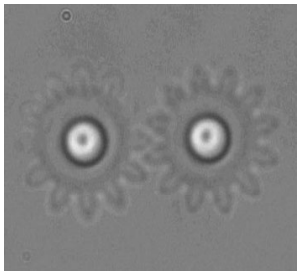

(b)
Fig. 4. Engaged microgears fabricated in different heights [(a) Fabrication method, (b) Engaged microgears] 


\title{
2 光子マイクロ光造形による光駆動マイクロギアの開発
}

\author{
非会員 井上 宏之* 非会員 芳賀 誠士* \\ 正 員 丸尾 昭二*
}

\section{Development of Optically Driven Microgears by Using Two-photon Microstereolithography}

Hiroyuki Inoue*, Non-member, Seiji Haga*, Non-member, Shoji Maruo*, Member

Two-photon microstereolithography can provide complicated three-dimensional microstructures with nearly $100 \mathrm{~nm}$ resolution in three-dimensions. This technique is one of promising methods to produce disposable functional biochips. However it needs a long time to fabricate thick microstructures owing to its high depth resolution. To solve this problem, we tried to control the thickness of microstructures by changing the numerical aperture of an objective lens and input laser power. As a result, we succeeded in fabricating microgears whose thickness is from $0.59 \mu \mathrm{m}$ to $1.57 \mu \mathrm{m}$. We also demonstrated that the optical torque of the thick microgear was higher than that of the thin microgear. Additionally the microgear was stably rotated by the optimization of the clearance between the gear and the shaft. Finally we fabricated engaged cogwheels by making each microgear at different height to avoid sticking of the two microgears.

キーワード : 2 光子マイクロ光造形法, 光トラッピング, マイクロギア

Keywords : two-photon microstereolithography, optically driven microgear, optical trapping

\section{1. 緒論}

近年, マイクロマシン技術の新たな応用分野として, DNA やタンパク質などの分析を行うマイクロ化学分析システム ( $\mu$-TAS) やバイオチップの開発が活発に行われている(1)。 これらの分野では, 従来のマイクロマシンのようにアクチ ユエータや検出回路が集積化された高度なデバイスより も, マイクロ流路や反応容器などの比較的単純な構造を安 価に作製することが求められる。なぜなら，バイオ八ザー ドを防ぐためには，安価なバイオチップを使い捨て利用す るのが好ましいからである。そこで, 従来の半導体マイク ロマシニングで用いられるシリコン基板ではなく, プラス チックやガラスなどの安価な基板を用いて, さまざまなバ イオチップが開発されている。しかし，マイクロ流路や反 応器だけを微小化したバイオチップでは, 高度な化学分析 プロセスの微量化, 高精度化, 自動化に限界がある。この ため最近では，使い捨て型バイオチップに，比較的単純な 構造のマイクロポンプやバルブを内蔵させる研究(2)(3)や, 空

* 横浜国立大学大学院 工学研究院 システムの創生部門 于 240-8501 神奈川県横浜市保土ヶ谷区常盤台 79-5 Division of Systems Integration, Yokohama National University

79-5 Tokiwadai, Hodogaya-ku, Yokohama, Kanagawa, 240-8501
気圧駆動によるバルブ(4)や光駆動型ポンプ(5)などを組み込 む研究が行われている。

我々のグループでも, 光駆動マイクロ流体制御素子の開 発を目的として，マイクロギアやマニピュレータなどさま ざまなマイクロ可動部品を試作してきた(6)(7)。これらのマイ クロ可動部品は, 光硬化性樹脂を用いて任意の 3 次元マイ クロ構造体を形成できる「2 光子マイクロ光造形法」(8)によ って作製される。我々の方式では, マイクロ流路と可動部 品がすべて光硬化性樹脂で形成されるため安価であり, 各 種流体制御素子は外部に設置したレーザー光によって遠隔 駆動させるため, 高価なアクチュエータを内蔵させる必要 がない。

本研究では, 光駆動マイクロマシンの基幹部品であるマ イクロギアを高精度かつ高効率に作製する手法について検 討を行った。具体的には, 2 光子マイクロ光造形法において, レンズの開口数（NA）と露光条件を変化させ，厚みの異な る光駆動マイクロギアを作製する手法を検討した。 2 光子マ イクロ光造形法では, 積層することで造形物の厚みを変化 させることができるが，支持構造なしで可動部品を造形す る場合には, 積層による厚みの再現性が低いという課題が あった。そこで, 本研究では, レンズの NA を変化させて, 可動部品の厚みの制御を安定かつ容易に行うことを目指 
す。本手法を用いれば，可動部品以外の構造体を積層造形 する際にも, 積層間隔を広げて, 高効率に 3 次元構造を造 形できるようになる。また，レンズの NA を小さくして， マイクロギアを厚肉化できれば，高い光駆動トルクを有す るマイクロマシンを実現できる。実際に，露光条件や NA を最適化させて厚肉マイクロギアを作製し，高精度かつ高 出力な回転駆動を可能とする形状を見いだした。さらに, 力伝達を可能とするかみ合い歯車の作製法を提案し, 実際 にマイクロギア列を試作した。

\section{2 光子マイクロ光造形法}

2 光子マイクロ光造形法では, 光硬化性樹脂を用いて, 立 体構造を形成する。通常, 光硬化性樹脂は紫外光で硬化さ せるが，2 光子吸収という非線形光学現象を利用すること で，紫外光の半分のエネルギーをもつ近赤外光でも樹脂を 硬化させることができる。ただし，一般に 2 光子吸収吸収 断面積は $10^{-50} \mathrm{~cm}^{4} \mathrm{~s} \mathrm{photon}^{-1}$ と小さい。そこで, フェムト 秒パルス光を用いて光強度を高め, NAの高いレンズで空間 的にも高密度に光を閉じ込めて, 2 光子吸収を誘起する。こ のとき, 2 光子吸収の発生確率は, 光強度の 2 乗に比例する ため, 光強度の高い焦点近傍の樹脂のみを選択的に硬化さ せることができる。その結果, 光の回折限界を超えたサブ ミクロンの加工線幅を得ることができる(9)。

さらに, 2 光子マイクロ光造形法には以下のような利点が ある。紫外光は樹脂表面近傍で吸収されてしまうのに対し て, 近赤外光は樹脂に対して透明であるため, 樹脂内部に レーザー光を集光して造形することができる。また，樹脂 は硬化前後の屈折率差が小さいため, 樹脂内部に造形物が 形成されても，レーザー光が乱されることが少なく，アス ペクト比の高い構造や, 複雑な 3 次元構造も高精度 - 高分 解能で造形することができる。

図 1 に, 本研究で用いた 2 光子マイクロ光造形装置の概

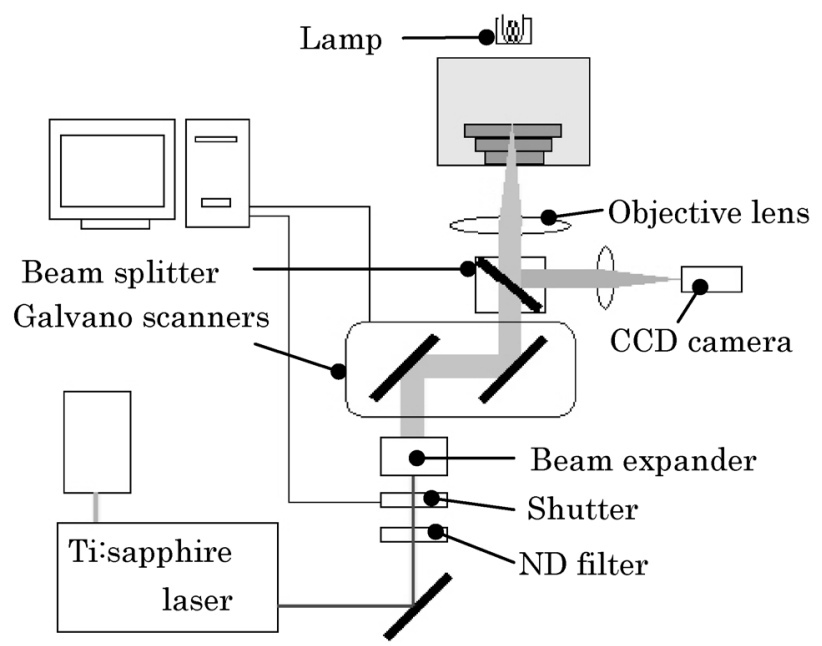

図 12 光子マイクロ光造形システム

Fig. 1. Fabrication system of two-photon microstereolithography.
略図を示す。本装置では, 光源に Ti:sapphire レーザー（波 長 : 750nm, パルス幅 : 200fs, 繰返し周波数 : $76 \mathrm{MHz}$ ) を用いている。レーザー光は, ND フィルター, シャッター を経て, ビームエキスパンダーでビーム径を広げた後, ガ ルバノミラーを通り, 対物レンズによって樹脂中に集光さ れる。従来の我々の実験では, NA：1.3 のレンズを用いた が(7), 本研究では, 対物レンズの NA を変化させて実験を行 うため, NA 可変の油浸対物レンズ (NA:0.5〜 1.35, 作動距 離: $0.1 \mathrm{~mm}$ ）を用いた。

\section{3. 低 NA，高出力による 2 光子造形}

紫外光を用いた通常の光造形法では, レーザーパワーを 上げれば硬化深さが非常に大きくなる(10)。これは, 紫外光 の吸収が 1 光子吸収であるため, 光強度に比例して硬化反 応が開始されるからである。

一方, 2 光子吸収では, 発生確率が光強度の 2 乗に比例す るため, 光吸収が光強度の強い焦点近傍に限定される。こ のため, 硬化領域は光強度を高めても, 1 光子吸収の場合ほ ど硬化深さを大きくすることができない。また, 高強度の パルス光を高 NA レンズで集光させた場合には, レーザー ブレイクダウンと呼ばれる現象が生じ，材料にダメージを 与えてしまう(11)。このため, 光硬化性樹脂を硬化させるこ とができる露光条件は制限される。

図 2 に, NA が 1.35 の場合に, レーザーパワーとレーザ 一走査速度を変えて, 造形可能な条件を調べた結果を示す。 レーザーパワーが弱い場合には樹脂が硬化せず，レーザー パワーが強い場合には，レーザーブレイクダウンによって, 樹脂内部に気泡が発生する現象が生じ, 造形物が破壊され てしまう。この実験では, 造形物として一辺 $50 \mu \mathrm{m}$ のフレ 一ム構造を造形した。このような比較的単純な形状であれ ば, 図 2 に示した範囲で造形可能だが, より複雑な形状を 安定に造形するには, さらに低レーザーパワー, 低速走査 の領域に限定される。

そこで, 単にレーザーパワーを上げるのではなく, NAを 変化させることで硬化領域を大きくすることを試みた。一 般に, 集光されたレーザー光は, 光学系に収差が無い場合 でも，無限小の 1 点に集まるのではなく，有限の大きさま でしか集めることができない。これを回折限界と言い,こ

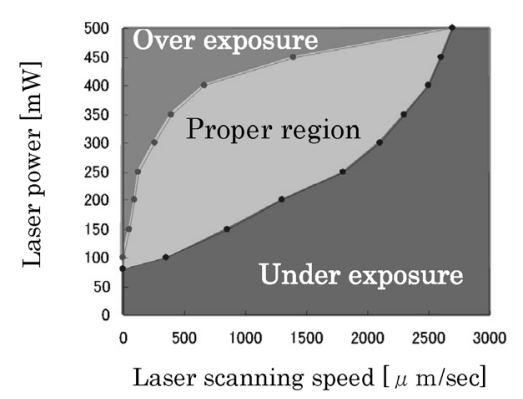

図 2 安定造形が可能な露光条件

Fig. 2. Proper exposure conditions for stable fabrication. 
のときの集光スポットの面内直径は式 ( 1 ) で与えられる。

$$
d=1.22 \frac{\lambda}{N A}
$$

また，焦点深度は式( 2)で与えられる。

$$
z=\frac{\lambda}{N A^{2}}
$$

ここで，入は光の波長を表す。したがって，低い NA の レンズでレーザーを集光すると, 焦点スポットが大きくな り，硬化領域は大きくなる。このとき，面内直径が NA に 反比例するのに対して, 焦点深度は $\mathrm{NA}^{2}$ に反比例するので, 硬化形状を焦点面内方向に比べ，光軸方向に大きくするこ とができる。これを利用すると， 1 層分のレーザー照射でア スペクト比の高い硬化層を得ることができる。ただし，NA を低くすると集光点での光密度が落ちるため, 2 光子吸収を 励起するために，レーザーパワーをさらに高くする必要が ある。

\section{4. マイクロギアの試作}

集光レンズの NA を変化させながら，前節と同様の予備 実験を行い，安定して造形が行えるレーザーパワーを決定

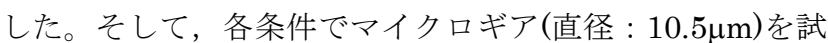
作し，ギアの厚みを調べた。実験では，レーザー光を中心 から同心円状に軌道半径を拡大しながら走査させ，ギア形 状を塗りつぶす方法で造形した。ギアの歯の部分では, レ ーザー光を高速走査させて, シャッターによる $\mathrm{ON}-\mathrm{OFF}$ 制御なしで連続的にレーザー光を走査させた。レーザー走 査速度は $30 \mu \mathrm{m} / \mathrm{sec}$ に固定して造形を行った。図 3 に,

$\mathrm{NA1} 1.25 ， 1.15 ， 1.05 ， 0.95$ と変化させ，それに伴いレーザ 一パワーを $100 \mathrm{~mW}, 150 \mathrm{~mW}, 200 \mathrm{~mW}, 250 \mathrm{~mW}$ と変化さ せてマイクロギアを造形した例を示す。図 3 に示したギア

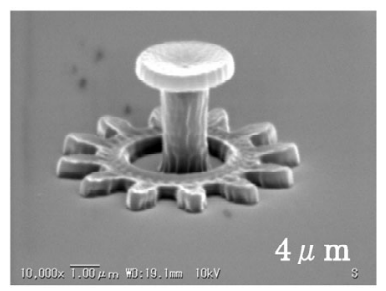

(a)

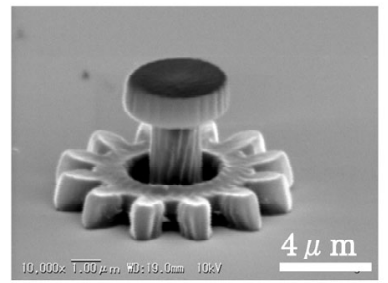

(c)

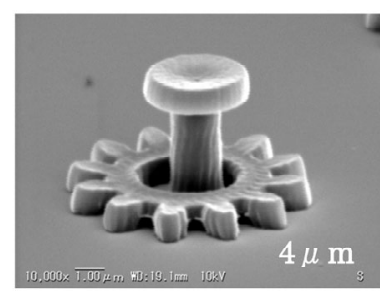

(b)

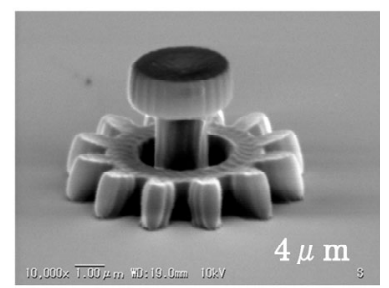

(d)
図 3 試作したマイクロギアの SEM 像

Fig. 3. SEM image of microgear〔(a) NA: 1.25, Laser Power: 100mW, (b) NA: 1.15, Laser Power: $150 \mathrm{~mW}$, (c) NA: 1.05, Laser Power: 200mW, (d) NA: 0.95, Laser Power: $250 \mathrm{~mW}$ ].
の厚さは, それぞれ $0.59 \mu \mathrm{m}, 0.97 \mu \mathrm{m}, 1.25 \mu \mathrm{m}, 1.57 \mu \mathrm{m}$ であった。このことから, NA とレーザーパワーを変化させ ることで，マイクロギアの厚みを制御できることが実証さ れた。ただし, 今回の実験では, ギアの厚みを増すと同時 にシャフト径も若干太くなっている。これは, 奥行分解能 と同時に, 面内分解能も変化するからである。しかし, 面 内の加工精度に関しては, 設計時に適切なオフセットを加 えることで, 容易に調節できるため, 所望のサイズの可動 部品を造形できると考える。

\section{5. マイクロギアの光駆動}

光トラッピングは, 光の放射圧を利用し, 物体をレーザ 一光の焦点で捕捉する技術である。光が物体に入射し屈折 すると, 光子の運動量変化が起き, これに反作用する力が 物体に働く。これを光の放射圧という(12)。

光トラッピングを用いてマイクロギアを回転させる方法 の概略図を図 4(a)に示す。この方法では, シャフトに拘束 されたマイクロギアの歯に, レーザー光を集光させて, そ の焦点を回転移動させる。図 4(b) は, ギアの歯にレーザー 光を集光させた際の断面図を表している。図中の矢印はギ アに働く放射圧の方向を示している。ギアの歯を捕捉した 状態から焦点を右へ移動させると，右向きの放射圧が働き， ギアは焦点に追従するように移動する。したがって，レー ザー光を走査することで, その軌跡に沿って物体を遠隔操 作することができる。

マイクロギアを回転させる力は, 図 4(b)に示すように, ギア側面に入射した光子の運動量変化から生じるものであ るので, 波長より大きい物体に対しては, レーザースポッ 卜径にも依存するが, 表面積の大きい物体の方が, より大 きい光トラップ力を得ることができる(13)(14)。したがって, サイズが同程度の場合, 側面積の大きいギアほど光トラッ プ力が増し, より高速にギアを回転させることができるの

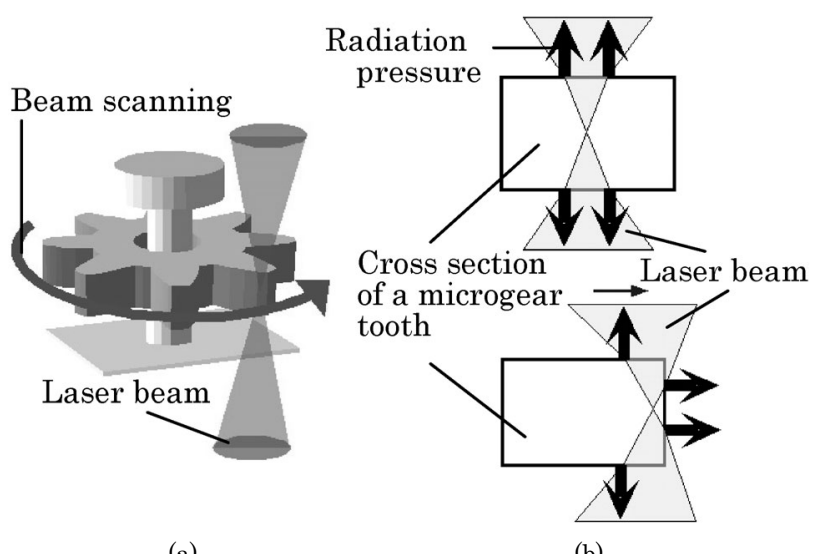

(a)

図４ママイクロギアの光駆動〔(a) マイクロギアの回転方法, (b) マイクロギアに作用する放射圧]

Fig. 4. Optical driving of a microgear〔(a) Rotation of a microgear, (b) Optical trapping force affected on a microgear]. 
で，厚肉マイクロギアの方が回転トルクが大きくなると考 えられる。

\section{6. 厚肉マイクロギアによる高出カ化}

厚みの異なるマイクロギアを光駆動させることで，厚み と回転数の関係を調べた。駆動実験は，未硬化樹脂を洗い 流すための有機溶媒であるグリコールエーテールアセテー 卜(動粘度 : $2.0 \mathrm{~mm}^{2} / \mathrm{s}$, 屈折率: 1.41 ) という溶媒中で行った。 実験に用いるマイクロギアは直径 $10.5 \mu \mathrm{m}$ で， 4 節と同じ条 件で造形したものである。また, 光駆動時のレーザーパワ 一は $500 \mathrm{~mW}$ である。実験ではレーザーの走査速度を徐々 に速めていき，マイクロギアがどの速さまで追従して回転 するかを調べた。この結果を図 5 に示す。この結果から, 実験を行った厚みの範囲では，マイクロギアの厚みと回転 数はほぼ比例関係になっていることがわかった。このこと から, 本実験で調査した範囲内では, 側面積の大きい厚肉 マイクロギアの方が, 光駆動時に光トラップ力を発生させ ることができ，マイクロマシンを高出力化できることを実

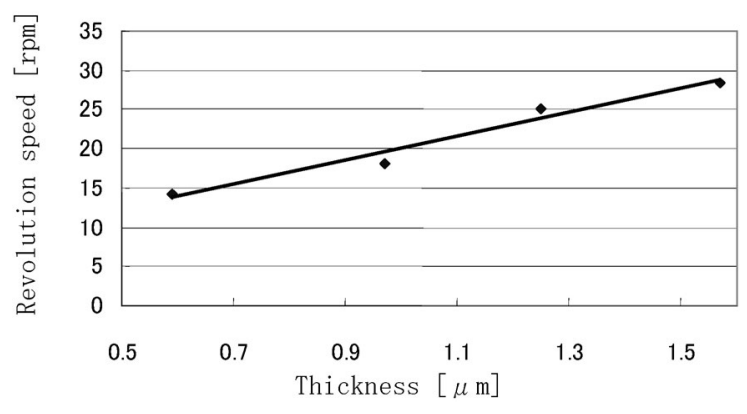

図 5 マイクロギアの厚みと回転数の関係

Fig. 5. Dependence of revolution speed on thickness of a microgear.

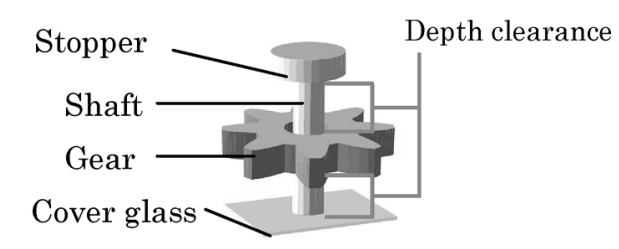

図 6 奥行クリアランスの定義

Fig. 6. Definition of depth clearance.

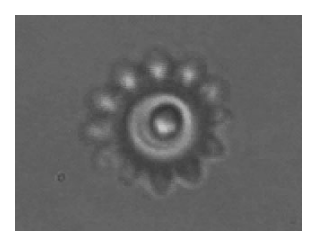

(a)

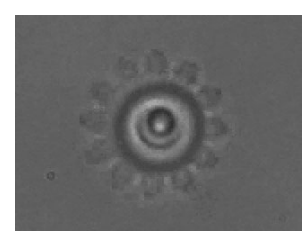

(b)
図 7 マイクロギアの回転の様子〔(a) 奥行クリアランス

$7.2 \mu \mathrm{m}$, (b) 奥行クリアランス $4.8 \mu \mathrm{m}]$

Fig. 7. Rotation of microgear 〔(a) $7.2 \mu \mathrm{m}$ depth clearance, (b) $4.8 \mu \mathrm{m}$ depth clearance].
証した。

\section{7. 光回転の高精度化}

マイクロギアを光トラッピングによって回転させる際 に, シャフトとのクリアランスを変化させて, 回転運動の 精度を検討した。まず, 図 6 に示す奥行クリアランス（造 形時に設けるカバーガラスとギア，およびギアとストッパ 一部のクリアランスの和）と回転の関係を調べた。クリア ランスは造形時に設ける層数によって調整した。回転数の 評価は, 光トラップ点がギアの歯からはずれずに, ギアが 追従して回転できる最大回転数を測定して行った。検証実 験に用いたギアはNA0.95 で造形されており, その直径は, すべて $10.5 \mu \mathrm{m}$ である。図 7 に奥行クリアランス $7.2 \mu \mathrm{m}(20$ 層分), および $4.8 \mu \mathrm{m}(10$ 層分) での回転時の様子を示す。回 転駆動実験は, レーザー光の回転中心とシャフトの中心を 合わせた状態で行った。しかしながら, 図 7(a)では奥行ク リアランスが大きいため, 光軸方向での回転ぶれと, ギア の回転中心とシャフトの中心が合わないという偏心が見ら れた。一方, 図 7(b)では, 偏心は少し残っているものの, 光軸方向の回転ぶれがほとんどなかった。このことから， 奥行クリアランスが小さくなることで回転の精度が向上し ていることがわかる。また，図 8 に示したように，奥行ク リアランスが小さくなっても, 回転数はわずかに減少する だけである。この減少はシャフトとギアの摩擦によるもの であると考えている。

次に, 図 9 に示す面内クリアランス（ギア穴とシャフト のクリアランス）と回転の関係を調べた。クリアランスは ギア穴径を固定し，軸径を太くすることで調整した。ギア の穴径はすべて $4.0 \mu \mathrm{m}$ である。図 10 に面内クリアランス $3.2 \mu \mathrm{m}$ (軸径 $1.0 \mu \mathrm{m}$ ), および $1.3 \mu \mathrm{m}$ (軸径 $2.8 \mu \mathrm{m}$ ) での回転時

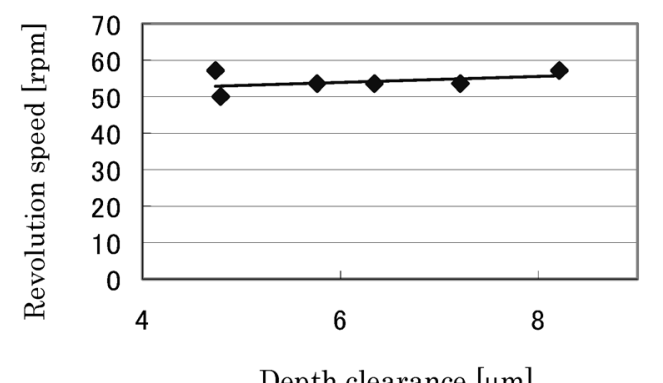

図 8 奥行クリアランスと回転数の関係

Fig. 8. Dependence of revolution speed on depth clearance.



図 9 面内クリアランスの定義

Fig. 9. Definition of lateral clearance. 
の様子を示す。図 10(a)では, 奥行方向の回転ぶれ, および 偏心が見られるが, 図 10(b)では, その両方が減少し, 安定 した回転を得ることができた。クリアランスを小さくする ことで，回転の安定性が大幅に向上したことがわかる。ま た, 図 11 に示したように, 面内クリアランスが小さくなっ ても, 奥行クリアランスと同様に, 回転数への影響は少な いことがわかる。

以上の実験により，奥行クリアランスを小さくすること で，奥行方向の回転ぶれを抑えられることがわかった。ま た，面内クリアランスを小さくすることで，奥行方向の回 転ぶれと偏心をともに抑えられることがわかった。これは, 光の放射圧によって奥行方向にもギアが捕捉されているた め, 奥行方向のクリアランスによる影響が少ないためであ ると考えられる。

次に, 二つのマイクロギアをかみ合わせる実験を試みた。 かみ合い回転を実現させるためには，二つのギアを高精度 に造形する必要がある。まず, シャフトの中心間距離を $10 \mu \mathrm{m}$ にして, 二つのマイクロギアを同一面内で造形するこ とを試みた（図 12(a))。この結果, 図 12(b)に示すように, ギアの歯同士が互いに引っ張り合うような形で接合してし まった。これは樹脂が硬化する際に, 周りの樹脂を引き込 みながら硬化し, 収縮するという特性が原因であると考え られる。これにより, 同一面内でかみ合ったギアを造形す るのは困難であることがわかる。そこで, 高さの異なる面 内で二つのギアを造形し，未硬化樹脂を洗浄した後に，か み合わせることを試みた（図 13(a)）。図 13(b)に中心間距離

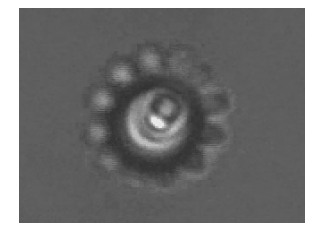

(a)

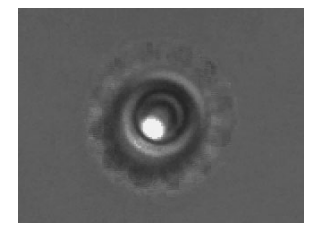

(b)
図 10 マイクロギアの回転の様子〔(a) 面内クリアランス $3.2 \mu \mathrm{m}$, (b) 面内クリアランス $1.3 \mu \mathrm{m}$ ]

Fig. 10. Rotation of microgear 〔(a) $3.2 \mu \mathrm{m}$ lateral clearance, (b) $1.3 \mu \mathrm{m}$ lateral clearance].

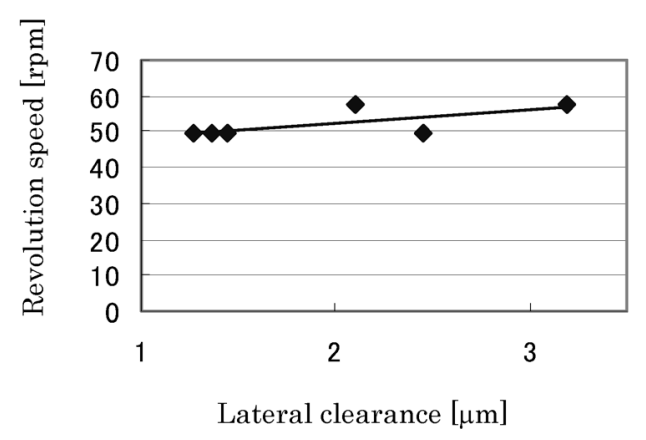

図 11 面内クリアランスと回転数の関係

Fig. 11. Dependence of revolution speed on lateral clearance.
を $9.5 \mu \mathrm{m}$ にして造形したときの液中写真を示す。この結果 から，二つのギアが接合することなく，かみ合っているこ とがわかる。この方法では, シャフトの長さが長くなって しまうという問題が生じるが，ギアとシャフトのクリアラ ンスが回転に与える影響を調べた前述の実験結果より, 奥 行クリアランスが大きい状態であっても, 面内クリアラン スが小さければ，ギアは安定して回転することが実証され ている。したがって, シャフトが長い状態でも, 安定した かみ合い回転が可能であると考えられる。

\section{8. 結 論}

本稿では, 2 光子マイクロ光造形において, NA, レーザ 一出力を変化させて造形することで, 造形物の厚みが制御 可能であることを実証した。低 NA, 高出力で造形すること で，厚さ $1.5 \mu \mathrm{m}$ 以上の厚肉マイクロギアを安定に作製する ことに成功した。また, ギアを厚肉化させることで, 光回 転トルクを向上させて, より高速な回転が可能であり, 面 内クリアランスを最適化させることにより, 奥行クリアラ ンスによらず，偏心の少ない安定した回転が得られること がわかった。さらに, 異なる面内で二つのギアを造形して, 2つのギアをかみ合わせることができた。今後, さらに厚 みのある構造を得るために, 可動部品を積層造形する手法 を確立する予定である。マイクロ可動部品をハイアスペク

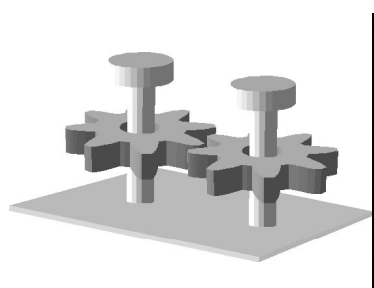

(a)

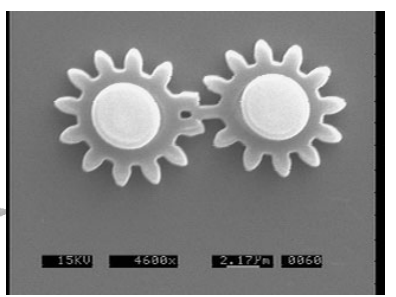

(b)
図 12 同一平面内でのかみ合わせギアの造形〔(a) 概略図, (b) かみ合わせギアの SEM 像(中心間距離 $10 \mu \mathrm{m}$ )]

Fig. 12. Engaged gears fabricated in the same height 〔(a) Schematic diagram, (b) SEM image of engaged gears with a center distance of $10 \mu \mathrm{m}]$.

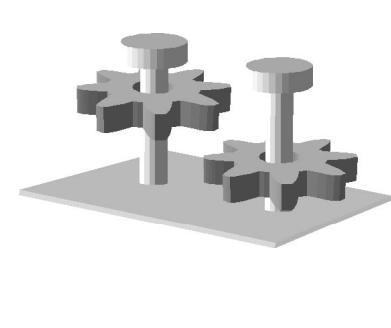

(a)

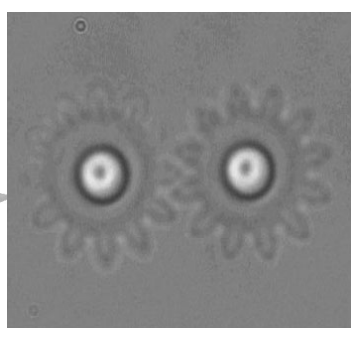

(b)
図 13 異なる高さでのかみあわせギアの造形〔(a) 概略図, (b) かみ合わせギアの光学顕微鏡像(中心間距離 $9.5 \mu \mathrm{m}$ )]

Fig. 13. Engaged gears fabricated in different heights 〔(a) Schematic diagram, (b) Optical image of engaged gears with a center distance of $9.5 \mu \mathrm{m}]$. 
ト化できれば，マイクロマシンの高出力化・高機能化が可 能であり，マイクロポンプ(15)などのマイクロ流体制御素子 への応用が期待される。

\section{謝 辞}

本研究は, 科学研究費補助金 (若手研究 $(\mathrm{A})$, 萌芽研究, 基盤研究（B)）および中谷電子計測技術振興財団，メカト ロニクス技術高度化財団, 財団法人安藤研究所, 高橋産業 経済研究財団の助成を受けて行われた。また，電子顕微鏡 観察にご協力いただいた横浜国立大学・八高隆雄教授に感 謝の意を表します。

(平成 17 年 8 月 29 日受付, 平成 18 年 2 月 16 日再受付)

\section{文献}

（1）北森武彦・庄子習一・馬場嘉信・藤田博之：マイクロ化学チップの 技術と応用，丸善 (2004)

(2) J. W. Choi, et al : "A disposable plastic biochip cartridge with on-chip power sources for blood analysis", Proc. of IEEE MEMS 2003, pp.447-500, Kyoto, Japan (2004-1)

(3) D. J. Beebe, et al. : "Functional hydrogel structures for autonomous flow control inside microfluidic channels", Nature, Vol.404, pp.588-590 (2000)

(4) J. S. Go, et al. : "A disposable, dead volume-free and leak-free monolithic PDMS microvalve", Proc. of Trans. 2003, pp.643-646, Boston, USA (2003-6)

(5) A. Terray, et al. : "Microfluidic control using colloidal devices", Science, Vol.296, pp.1841-1844 (2002)

(6) S. Maruo, et al. : "Two-photon-absorbed near-Infrared photopolymerization for three-dimensional microfabrication", $J$. of Microelectromechanical Syst., Vol.12, pp.533-539 (2003)

(7) S. Maruo, et al. : "Submicron manipulation tools driven by light in a liquid", Appl. Phys. Lett., Vol.82, pp.133-135 (2003)

(8) S. Maruo, et al., "Three-dimensional microfabrication with two-photon absorbed photopolymerization", Opt. Lett., Vol.22, pp.132-134 (1997)

(9) S. Kawata, et al. : "Finer features for functional microdevices", Nature, Vol.412, pp.697-698 (2001)

(10) S. Zissi, et al. : "Stereolithography and microtechniques", Microsystem Tech., Vol.2, pp.97-102 (1996)

(11) C. B. Schaffer, et al. : "Dynamics of femtosecond laser-induced breakdown in water from femtoseconds to microseconds", Opt. Express, Vol.10, pp.196-203 (2002)

(12) A. Ashkin, et al. : "Observation of a single-beam gradient force optical trap for dielectric particles", Opt. Lett. Vol.11, pp.288-290 (1986)
(13) R. C. Gauthier, et al. : "Experimental confirmation of the optical-trapping properties of cylindrical objects", Appl. Opt. Vol.38, pp.4861-4869 (1999)

（14）浮田宏生：マイクロメカニカルフォトニクス，森北出版（2002）

(15) S. Maruo and H. Inoue : "Optically driven micropump produced by two-photon microstereolithography", Proc. of Ninth International Conference on Miniaturized Systems for Chemistry and Life Sciences ( $\mu$ TAS 2005), pp.590-592, Boston, USA (2005-10)

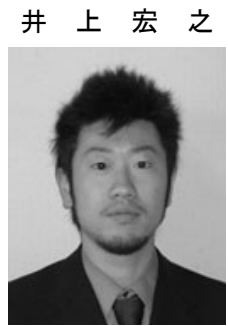

（非会員） 1982 年生。 2005 年 3 月横浜国立大 学卒業。現在, 横浜国立大学大学院システム統 合工学専攻修士課程に在籍。 2 光子マイクロ光 造形法を用いたマイクロマシンの開発とその 応用研究に従事。

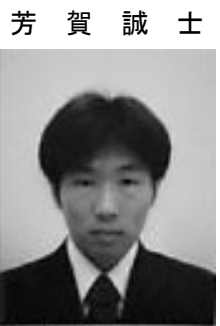

（非会員） 1979 年生。 2005 年 4 月横浜国立大 学大学院工学研究院システム統合工学専攻修 士課程修了。在籍中は, 2 光子マイクロ光造形 法を用いた光駆動マイクロマシンの開発に従 事。現在，キヤノン株式会社に勤務。

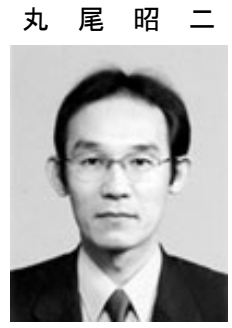

(正員) 1970 年生。1992 年大阪大学工学部応 用物理学科卒。1997 年大阪大学大学院工学研 究科応用物理学専攻博士後期課程修了。博士 (工学)。日本学術振興会未来開拓プロジェク 卜研究員, 日本学術振興会特別研究員, 名古屋 大学工学部助手を経て, 2003 年 4 月より横浜 国立大学大学院・助教授。マイクロ光造形法, 光駆動マイクロマシン等に関する研究に従事。 IEEE, 応用物理学会, 日本機会学会, 日本ロボット学会, 化学と マイクロ・ナノシステム研究会各会員。 